\title{
Plasma concentrations of FSH and LH in entire and castrated prepubertal bull calves treated with Gn-RH
}

\author{
J. J. Bass*, A. S. McNeilly $\dagger$ and H. E. Moreton \\ Meat Research Institute, Langford, Bristol, and $\uparrow$ M.R.C. Reproductive Biology Unit, \\ 2 Forrest Road, Edinburgh, U.K.
}

\begin{abstract}
Summary. In bulls there was no increase in plasma FSH and only a small increase in LH over the first 14 weeks of age. In steers (castrated) plasma LH and FSH were unchanged for the first 3 weeks but increased significantly at 7 and 14 weeks. After $100 \mu \mathrm{g} \mathrm{Gn-RH,} \mathrm{LH}$ release in bulls was minimal until 7 and 14 weeks and there was no comparable rise for FSH. LH and FSH responded to Gn-RH throughout the trial in the steers. The neonatal calf testes selectively inhibited the release of FSH from the pituitary even when challenged with Gn-RH.
\end{abstract}

\section{Introduction}

Plasma concentrations of luteinizing hormone $(\mathrm{LH})$ in entire and castrated bulls fall immediately after birth and then gradually rise until 28 days when the values of plasma LH in the steers increase rapidly above those of entire bulls (Bass, Peterson, Payne \& Jarnet, 1977). LH is released in prepubertal bulls in response to the administration of synthetic gonadotrophinreleasing hormone (Gn-RH) (Mongkonpunya, Hafs, Convey, Tucker \& Oxender, 1975; Kesler \& Garverick, 1977) but the effect of castration on release of $\mathrm{LH}$ and follicle-stimulating hormone (FSH) in response to Gn-RH stimulation in prepubertal bull calves has not been reported. The present study was undertaken to investigate the effect of castration of prepubertal bulls on plasma concentrations of LH and FSH and the response of these hormones to Gn-RH.

\section{Materials and Methods}

Two British Friesian bull calves castrated at birth (steers) and two entire bull calves (bulls) were reared in individual pens under identical management conditions. The birth weights $(41 \cdot 5-46 \cdot 0$ $\mathrm{kg}$ ) and final liveweights (61-64 kg) were similar for the steers and bulls.

At 1, 2, 3, 7 and 14 weeks of age, between 09:00 and 10:00 h, jugular vein blood was collected by venepuncture at $40,30,20 \mathrm{~min}$ and immediately before the intravenous administration of $100 \mu \mathrm{g} \mathrm{Gn-RH} \mathrm{(Gonadorelin:} \mathrm{Ayerst).} \mathrm{Samples} \mathrm{were} \mathrm{then} \mathrm{collected} \mathrm{at} \mathrm{30,60}$ and 90 min after the GN-RH injection. After centrifugation the plasma was stored at $-20^{\circ} \mathrm{C}$ until analysis.

The concentrations of $\mathrm{LH}$ and FSH in the plasma were measured using the radioimmunoassays described by Scaramuzzi, Caldwell \& Moor (1970) and McNeilly, McNeilly, Walton \& Cunningham (1976) respectively. These assays, originally developed for measuring ovine LH and FSH, were tested for specificity by using the following bovine pituitary hormone preparations: LH (NIH-LH-B8); FSH (CH-1-76; potency $164 \times$ NIH-FSH-S1); TSH (30

* Present address: Meat Section, Ruakura Animal Research Station, Hamilton, New Zealand. 
i.u./mg, Pierce); prolactin (NIH-P-B12); and GH (NIH-GH-B15). Each hormone preparation was tested in double dilution from $5 \mu \mathrm{g} / \mathrm{ml}$. The $\mathrm{LH}$ assay was specific for $\mathrm{LH}$ and all other hormone preparations tested showed $<0.1 \%$ cross-reaction (w/w at $50 \% \mathrm{~B} / \mathrm{Bo}$ ). Similarly, the FSH assay was specific for FSH and cross-reaction with all other hormone preparations was also $<0.1 \%(\mathrm{w} / \mathrm{w}$ at $50 \% \mathrm{~B} / \mathrm{Bo})$. It had been established previously that no serum interference occurred in either radioimmunoassay (Scaramuzzi et al., 1970; McNeilly et al., 1976). Dilution curves of plasma from cows and bulls were parallel to the respective standards in each assay. Recovery of added hormone to plasma and intra-assay variation as coefficient of variation was $98 \pm 4 \%$ and $7 \%(n=30)$, and $101 \pm 5 \%$ and $8 \%(n=40)$ in the LH and FSH assays respectively. All samples were assayed at two dilutions $(1: 2$ and $1: 10)$ in one assay to reduce variability. Results are expressed in terms of NIH-LH-B8 and NIH-FSH-B1 for LH and FSH respectively.

Differences in hormone concentrations within individuals were assessed by obtaining the hormone concentrations within age before and after $\mathrm{Gn}-\mathrm{RH}$ injections. Statistical significance was examined by using the $\mathrm{F}$ test on logarithmically transformed data.

\section{Results}

\section{Preinjection plasma concentrations and the response to $100 \mu \mathrm{g} G \mathrm{G}-\mathrm{RH}$}

$L H$. The plasma concentrations of $\mathrm{L} \cdot \mathrm{H}$ in the bulls and steers were similar for the first 7 weeks (Text-fig. 1a), but by 14 weeks of age values were relatively higher in the steers. When the preinjection samples at each age were combined for individual animals, Bull B (0.85 to 1.60), Steer C $(1.23$ to 2.45$)$ and Steer D $(1.09$ to 4.89$)$ had significantly $(P<0.01)$ higher LH plasma concentrations $(\mathrm{ng} / \mathrm{ml})$ at 14 weeks (proportional s.e. $\times 100=13.4 \%)$ than at 1 week (proportional s.e. $\times 100=14 \cdot 1 \%$ ) of age.

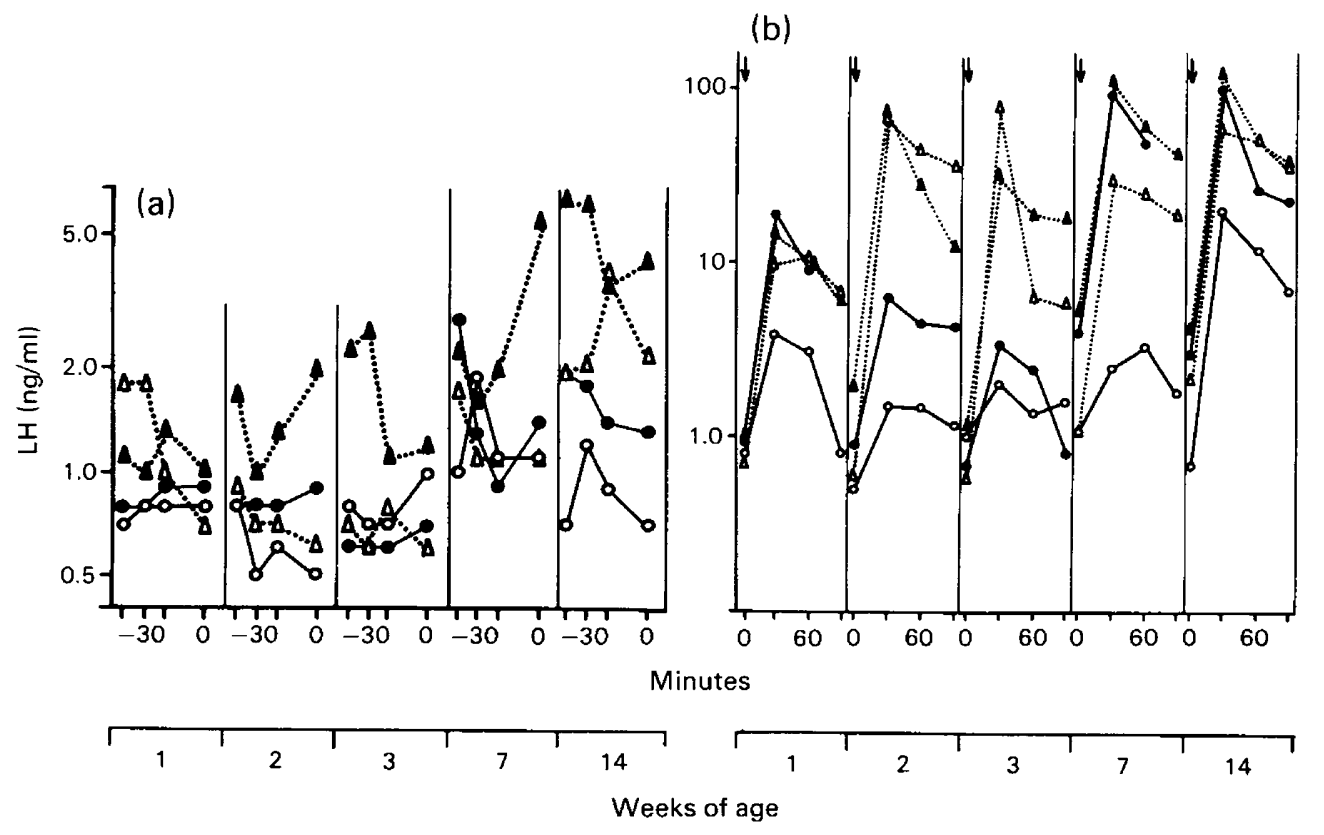

Text-fig. 1. Plasma LH concentrations in Bulls $A(O)$ and B (O) and Steers $C(\Delta)$ and D (A) before (a) and after (b) injections of $100 \mu \mathrm{g} \mathrm{Gn-RH}$ (arrows) at different ages after birth. 
The LH response to Gn-RH increased from Weeks 1 to 14 in both bulls and steers $(P<$ 0.01 ) (Text-fig. 1b) although the dose fell from 2.3 to $1.6 \mu \mathrm{g}$ per $\mathrm{kg}$ liveweight.

$F S H$. The preinjection plasma concentrations of FSH in both bulls and steers were similar and remained below $300 \mathrm{ng} / \mathrm{ml}$ until at least 3 weeks of age (Text-fig. 2a). The levels in the bulls remained at these low concentrations throughout the trial whereas the steers showed markedly higher concentrations $(P<0.05)$ at 14 weeks than at 1 week of age. The combined individual concentrations of FSH before Gn-RH showed that there was a significant $(P<0.001)$ rise from 1 to 14 weeks of age in steers but not in bulls. The administration of $\mathrm{Gn}-\mathrm{RH}$ had no significant effect on the concentration of FSH in bulls $(<300 \mathrm{ng} / \mathrm{ml})$ but had a marked $(P<0.05)$ effect in steers (Text-fig. 2b), mean plasma concentrations reaching values greater than $1300 \mathrm{ng} / \mathrm{ml}$. There were significant differences $(P<0.01)$ between the combined individual data for FSH after Gn-RH from Weeks 1 to 14 for the steers but no differences for the bulls. There was also a significant difference $(P<0 \cdot 1)$ in relative increase to $\mathrm{Gn}$ - RH between bulls and steers at 1 week of age.

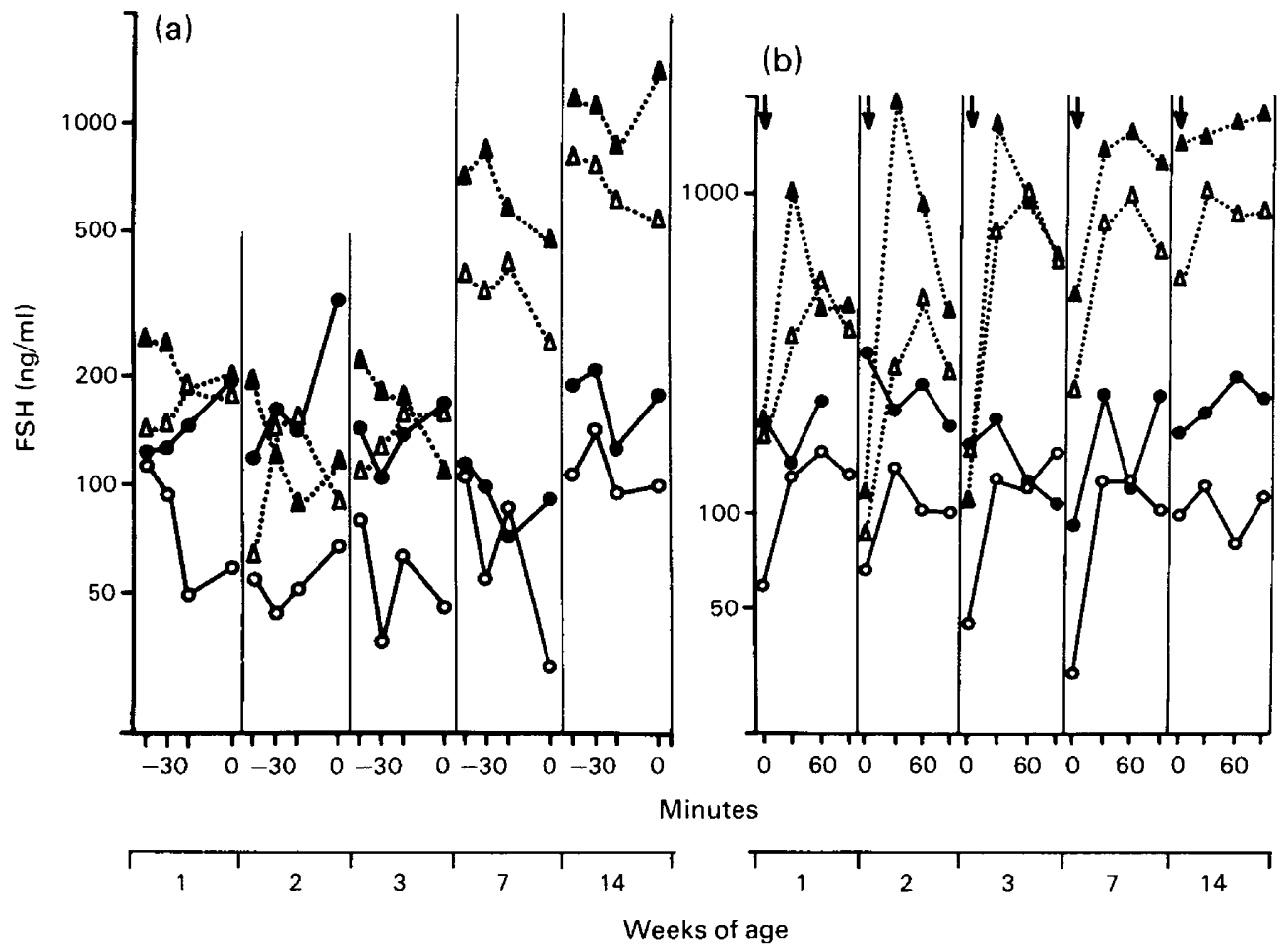

Text-fig. 2. Plasma FSH concentrations in Bulls $A(O)$ and $B(C)$ and Steers $C(\triangle)$ and D (A) before (a) and after (b) injections of $100 \mu \mathrm{g} \mathrm{Gn}-\mathrm{RH}$ (arrows) at different ages after birth.

\section{Discussion}

Although only 4 animals were involved in this study significant differences were found between the steers and bulls in response to $\mathrm{Gn}-\mathrm{RH}$. In agreement with earlier reports (Mongkonpunya et al., 1975; Karg et al., 1976) we found no increase in FSH levels and only a slight increase in LH levels in bulls during the neonatal period. Castration caused no marked response in plasma concentrations of $\mathrm{LH}$ and FSH during the first 3 weeks of age. A similar refractory period has been reported for LH (Bass et al., 1977). 
The small release of $\mathrm{LH}$ by the pituitary in response to a Gn-RH challenge in the first 3 weeks of life agrees with the data of Kesler \& Garverick (1977) who found no change in response to Gn-RH during the first 25 days. The $\mathrm{LH}$ increase at 7 and 14 weeks of age to Gn$\mathrm{RH}$ is in agreement with work on ram lambs (Galloway \& Pelletier, 1974) but not with that on bull calves (Mongkonpunya et al., 1975).

The FSH concentrations in the bulls remained low throughout the experiment and were not stimulated by Gn-RH, but in the steers there was a marked increase in plasma FSH and a significant increase in relative response to $\mathrm{Gn}-\mathrm{RH}$ at 1 week of age. Our results suggest that the presence of the testes inhibits the release of FSH from the pituitary when challenged with GnRH during the neonatal period.

\section{References}

Bass, J.J., Peterson, A.J., Payne, E. \& Jarnet, M.P. (1977) The effect of neonatal estrogen treatment on plasma hormone levels and behaviour in pre- and post-pubertal bulls. Theriogenology 8, 59-71.

Galloway, D.G. \& Pelletier, J. (1974) Influence of age on the pituitary response of male lambs to synthetic $\mathrm{LH}$ RH injection. Horm. Metab. Res. 6, 240-241.

Karg, H., Gimenez, Hartl, M., Hoffmann, B., Schallenberger, E. \& Schams, D. (1976) Testosterone, Luteinizing Hormone (LH) and Follicle Stimulating Hormone (FSH) in peripheral plasma of bulls; levels from birth through puberty and short term variations. Zentbl. VetMed. A 23, 793-803.

Kesler, D.J. \& Garverick, H.A. (1977) Luteinizing hormone and testosterone concentrations in plasma of bull calves treated with gonadotropin releasing hormone. J. Dairy Sci. 60, 632-634.
McNeilly, J.R., McNeilly, A.S., Walton, J.S. \& Cunningham, F.J. (1976) Development and application of a heterologous radioimmunoassay for ovine follicle-stimulating hormone. J. Endocr. 70, 69-79.

Mongkonpunya, K., Hafs, H.D., Convey, E.M., Tucker, H.A. \& Oxender, W.D. (1975) Serum luteinizing hormone, testosterone and androstenedione in pubertal and prepubertal bulls after gonadotropin releasing hormone. J. Anim. Sci. 40,682-686.

Scaramuzzi, R.J., Caldwell, B.V. \& Moor, R.M. (1970) Radioimmunoassay of $\mathrm{LH}$ and estrogen during the estrous cycle of the ewe. Biol. Reprod. 3, 110-119.

Received 13 February 1979 